\title{
Dominants of investment and innovation policy of ensuring sustainable development of the natural resource potential
}

\author{
Boris Burkinsky ${ }^{1}$, Natalya Andryeyeva ${ }^{1}$, Oksana Nikishyna ${ }^{1}$, and Hanna Tiutiunnyk ${ }^{1, *}$ \\ ${ }^{1}$ Institute of Market Problems and Economic and Ecological Research of National Academy of \\ Sciences of Ukraine, 65044 Odessa, Ukraine
}

\begin{abstract}
The study presents a comprehensive assessment of the dominants of investment and innovation policy of nature management. The results of expert and integrated assessment of strategic priorities of investment and innovation policy of sustainable development in Ukraine are obtained. The shortcomings and "bottlenecks" are identified, the ways of increasing the efficiency of the current investment and innovation policy, the directions of its adjustment taking into account both internal trends of sustainable development and external trends of environmental management and best practices of European countries are substantiated. A comprehensive assessment of the degree of implementation of the dominants of investment and innovation policy and components through the prism of the Goals and Objectives of Sustainable Development. The diagnostics of the efficiency of the current investment and innovation policy is carried out and the directions of its adjustment to increase the degree of implementation of the key dominants of the investment and innovation policy of sustainable development are substantiated. The article enriches the ongoing scientific discourse on the role of investment and innovation policy of nature resource management in the context of sustainable development.
\end{abstract}

\section{Introduction}

All states, regardless of their natural resource potential and geopolitical location, face the challenges of depletion of limited natural resources and climate change. The response to these challenges requires the development of new methods and techniques that promote sustainable economic growth and are based on ensuring close interaction between the economy, the natural environment and the quality of life of the population. Through this, it is necessary to develop methodological support for quantitative and qualitative assessment of the dominants of the investment and innovation policy of natural resource management based on the principles of sustainable development and to conduct on its basis a systematic diagnosis of current trends and problems of investment and innovation support of natural resource management.

*Corresponding author: ecoregnaturres@ukr.net 


\section{Methods}

The research is closely related to the institutions of sustainable development, in particular, the program for implementing the Sustainable Development Goals until 2030, proclaimed by the UN General Assembly Resolution No. 70/1 of 25.09.2015 by the Presidential Decree No. 722/2019 of 30.09.2019 [1], the Sustainable Development Strategy of Ukraine until 2030 [2].

The results of the comprehensive evaluation of the dominants of the investment and innovation policy of natural resource management proposed by the authors and the results of an expert and integrated evaluation of the strategic priorities of the investment and innovation policy of sustainable development in Ukraine allow us to identify the disadvantages and "narrow" places in the process of its implementation, to substantiate the ways to improve the effectiveness of the current investment and innovation policy of natural resource management, the directions of its adjustment taking into account both internal trends of sustainable development and external trends in rational use of natural resource management and best practices of European states.

The main goal of the study is a comprehensive evaluation of the degree of implementation of the dominants of the investment and innovation policy of natural resource management and their components through the prism of the SDGs (Sustainable Developmen Goals) and objectives, measuring the progress of sustainable development of the national economy, as a methodological basis for diagnosing the effectiveness of the current investment and innovation policy of natural resource management and justifying the directions of its adjustment to increase the degree of implementation of the key dominants of investment and innovation policy of sustainable development.

\section{Results and discussion}

The current methodology for monitoring and evaluating the effectiveness of state regional policy [3], which integrated 61 indicators in 11 areas, provides only 5 indicators for evaluation of the rational use of natural resources and environmental quality, which relate only to the ecological capacity (carbon and waste intensity) of the regional economy. These indicators include, in particular, the volume of emissions of pollutants from stationary sources by 1 billion UAH. GRP, the rate of their growth (decrease) per unit of population, the share of waste removed to specially designated places or objects or burned in the total volume of waste generated, the share of settlements with separate collection of household and similar waste.

At the same time, the section "Investment and innovation development and foreign economic cooperation" does not contain indicators for evaluation of the dynamics of environmentally oriented investments and innovations, the section "Renewable energy and energy efficiency" contains one indicator of the energy efficiency of the regional economy [3-4]. But, external funding sources that come from investment, stimulates the increase of innovative ideas surrounding technological advances while it also holds the potential to decrease unemployment [5] (Table 1).

In the EU countries, a number of environmental indicators are used to evaluate the state of the natural environment and the effectiveness of environmental policies, which are classified according to the scheme of the European Environment [6-7]:

$$
D-P-S-I-R(D P S I R)
$$

where $D$-driving forces - socio-economic factors that increase or decrease the load on the environmental protection; 
$P$ - pressure - direct anthropogenic load on the environment, carried out through emissions and discharges of pollutants, the use of natural resources;

$\mathrm{S}$ - state - current state and trends of environmental protection changes;

I - impact - consequences of environmental changes for public health, nature and biodiversity;

$\mathrm{R}$ - responses - certain actions to solve environmental problems.

Table 1. Dynamics of the rating of some countries by the Innovation Efficiency Index for 2010-2018.

\begin{tabular}{|l|c|c|c|c|c|c|c|}
\hline \multicolumn{1}{|c|}{ Country } & $\mathbf{2 0 1 0}$ & $\mathbf{2 0 1 2}$ & $\mathbf{2 0 1 4}$ & $\mathbf{2 0 1 5}$ & $\mathbf{2 0 1 6}$ & $\mathbf{2 0 1 7}$ & $\mathbf{2 0 1 8}$ \\
\hline Ukraine & 54 & 14 & 14 & 15 & 12 & 11 & 5 \\
\hline Kazakhstan & 77 & 131 & 118 & 124 & 108 & 116 & 111 \\
\hline China & 14 & 1 & 2 & 6 & 7 & 3 & 3 \\
\hline USA & 63 & 70 & 57 & 33 & 25 & 21 & 22 \\
\hline Germany & 56 & 11 & 19 & 13 & 9 & 7 & 9 \\
\hline Poland & 85 & 80 & 76 & 93 & 66 & 48 & 42 \\
\hline India & 101 & 2 & 31 & 31 & 63 & 53 & 49 \\
\hline Japan & 18 & 88 & 88 & 78 & 65 & 49 & 44 \\
\hline Switzerland & 15 & 5 & 6 & 2 & 5 & 2 & 1 \\
\hline Luxembourg & 5 & 8 & 9 & 3 & 1 & 1 & 2 \\
\hline
\end{tabular}

Source: generated based on [6].

According to the system of analysis according to methodological scheme (1), socioeconomic development increases the pressure on the environmental protection and, as a result, generates changes in the environment [7, 8]. In our opinion, the methodological scheme of the European Environment Agency (1) can be used in the course of the author's methodology for determining the dominants of the investment and innovation policy of natural resource management and grouping indicators for a comprehensive evaluation of the degree of their implementation in Ukraine.

The methodological approach to the comprehensive evaluation of the dominants of the investment and innovation policies of the national economy, proposed by the authors, combines the conceptual and methodological basis, the components of which are shown in Table 2-3. An integral part of the methodological approach is the principles of integrated evaluation of the dominants of the investment and innovation policy of natural resource management, which include the following (see Fig. 1):

1) consistency and complexity;

2) adequacy and dynamism;

3) objectivity and accuracy;

4) effectiveness;

5) purposefulness;

6) scientific nature.

The law "On the Basic Principles (Strategy) of the State Environmental Policy of Ukraine for the Period up to 2030" No. 2697-VII of 28.02.2019 [7] defines five strategic goals aimed at achieving the state environmental policy, namely: formation of environmental values and principles of sustainable consumption and production in society; ensuring sustainable development of the natural resource potential of Ukraine; ensuring the integration of environmental policy into the decision-making process on socio-economic development of Ukraine; reducing environmental risks in order to minimize their impact on ecosystems, socio-economic development and public health; improvement and development of the state system of natural resource management. 
Table 2. The methodological approach to the comprehensive assessment of the dominants of IIPNM (Investment-Innovation Policy of Nature Management) on the basis of sustainable development (Conceptual basis).

Conceptual basis: concepts of sustainable development, "green" growth, circular economy, innovative development of socio-economic system based on "quadro-spiral"

The purpose of the methodological provisions: a comprehensive assessment of the degree of implementation of the dominants of Investment-Innovation Policy of Nature Management and their components through the prism of the goals and objectives of sustainable development, measuring the progress of sustainable development of the national economy, as methodical basis for diagnosing the effectiveness of the current Investment-Innovation Policy of Nature Management and substantiation of the directions of its adjustment to increase the degree of implementation of key dominants of investment and innovation policy of sustainable development.

\section{Tasks of methodical provisions:}

1. Systematization of information flows in terms of the main directions of complex assessment of IIPNM dominants and their components

2. Assessment of the state and dynamics of economic and environmental indicators in terms of goals and objectives of sustainable economic development

3. Assessment of interrelation and correlation of various indicators both within a certain dominant of IIPNM, and indicators of various dominants

4. Determining the results of a comprehensive assessment of negative trends and "bottlenecks" in the process of sustainable development

5. Generalization and qualitative assessment of the dynamics of changes in indicators of investment and innovation policy of sustainable development

6. Substantiation of ways and directions of increase of degree of introduction of dominants of IIPNM taking into account the European practices

Principles of comprehensive assessment of the dominants of investment and innovation policy of sustainable development

\begin{tabular}{|l|l|}
\hline $\begin{array}{l}\text { 1. Systematic and } \\
\text { comprehensive }\end{array}$ & $\begin{array}{l}\text { The assessment of the dominance of IIPNM, as a complex system } \\
\text { of goals and objectives of sustainable development, is carried out } \\
\text { taking into account all the internal and external links between its } \\
\text { elements and their interdependence }\end{array}$ \\
\hline $\begin{array}{l}\text { 2. Adequacy and } \\
\text { dynamism }\end{array}$ & $\begin{array}{l}\text { Correspondence of methods and receptions of an estimation to } \\
\text { modern laws of fluidity of processes of reproduction in } \\
\text { circulating economy, diagnostics of dominants of IIPNM in } \\
\text { constant development of social and economic systems }\end{array}$ \\
\hline $\begin{array}{l}\text { 3. Objectivity and } \\
\text { accuracy }\end{array}$ & $\begin{array}{l}\text { The information base for a comprehensive assessment must be } \\
\text { reliable, and its results must be based on accurate analytical } \\
\text { calculations }\end{array}$ \\
\hline 4. Effectiveness & $\begin{array}{l}\text { The results of the assessment of the achievement of the SDG } \\
\text { should be of practical importance, serve as an analytical basis } \\
\text { for adjusting the dominance of IIPNM, justification of } \\
\text { adaptive mechanisms of sustainable development in crisis } \\
\text { conditions }\end{array}$ \\
\hline 5. Purposefulness & $\begin{array}{l}\text { Focus on achieving the main goal of the methodology - a } \\
\text { comprehensive assessment of the degree of implementation of } \\
\text { the dominants of IIPNM in the coordinates of the Goals and } \\
\text { objectives of sustainable development of the state }\end{array}$ \\
\hline 6. Scientific & $\begin{array}{l}\text { Continuous improvement of methods for diagnosing the } \\
\text { dominance of IIPNM and the use of world best practices for } \\
\text { assessing the progress of sustainable development }\end{array}$ \\
\hline
\end{tabular}

Source: Compiled by the authors. 
Table 3. The methodological approach to the comprehensive assessment of the dominants of IIPNM on the basis of sustainable development (Methodical provisions on comprehensive assessment of IIPNM dominants).

\begin{tabular}{|c|c|}
\hline \multicolumn{2}{|c|}{$\begin{array}{l}\text { Methodical provisions on comprehensive assessment of IIPNM dominants. The main } \\
\text { stages of evaluation: I. Comprehensive assessment of the degree of implementation of } \\
\text { IIPNM dominants using groups of indicators of sustainable development: }\end{array}$} \\
\hline ominants of IIPNM & Groups of evaluation indicators \\
\hline he & $\begin{array}{l}\text { 1.1. Share of environmental investments in GDP } \\
\text { and budget expenditures } \\
1.2 \text {. Dynamics and structure of capital } \\
\text { investments for environmental protection } \\
\text { 1.3. Dynamics and structure of current } \\
\text { investments in environmental protection } \\
\text { 1.4. Dynamics of total environmental protection } \\
\text { costs in the sectoral dimension }\end{array}$ \\
\hline & $\begin{array}{l}\text { aastructure } \\
\text { ive activity of the } \\
\text { y } \\
\text { on research and } \\
\text { nable development } \\
\text { nol }\end{array}$ \\
\hline $\begin{array}{l}\text { d } \\
\text { al }\end{array}$ & $\begin{array}{l}3 \\
1 \text { la } \\
\text { fi } \\
\text { d }\end{array}$ \\
\hline & \\
\hline & \\
\hline \multicolumn{2}{|c|}{$\begin{array}{l}\text { II. Assessment of deviations of actual values of indicators from targets of sustainable } \\
\text { development and levels of indicators of OECD countries, determination of tendencies of } \\
\text { sustainable development in internal and external dimension. }\end{array}$} \\
\hline \multicolumn{2}{|c|}{$\begin{array}{l}\text { III. Determining the causes of deviations, causal links between economic and } \\
\text { environmental indicators of sustainable development, problematic aspects of the } \\
\text { introduction of the dominant IIPNM. } \\
\text { IV. Qualitative assessment of the dynamics of changes in indicators, aggregate conclusion } \\
\text { about the state of achievement of the SDG. } \\
\text { V. Expert and integrated assessment of the degree of implementation of the dominant } \\
\text { IIPNM of the national economy. } \\
\text { VI. Substantiation on the results of a comprehensive assessment of directions and ways to } \\
\text { increase the degree of implementation of the dominants of IIPNM on the basis of } \\
\text { sustainable development }\end{array}$} \\
\hline \multicolumn{2}{|c|}{$\begin{array}{l}\text { Incentive mechanisms introduction of ecologically oriented investments and innovations } \\
\text { in the activities of economic entities of different sectors of the economy: } \\
\text { 1. Institutional; } 3 \text {. Administrative; } \\
\text { 2. Financial and economic; } 4 \text {. Information }\end{array}$} \\
\hline
\end{tabular}

Source: Compiled by the authors.

Integrated scores of the degree of implementation of the dominants of the investment and innovation policy of natural resource management and their components and tasks with the lowest level of implementation are summarized in Table 4. 
Table 4. Components of IIPNM dominants and tasks with the lowest level of implementation in Ukraine ${ }^{*}$.

\begin{tabular}{|c|c|c|c|c|c|}
\hline $\begin{array}{l}\text { Dominants of } \\
\text { IIPNM }\end{array}$ & Rating & Level & \begin{tabular}{|c|}
$\begin{array}{c}\text { Components of dominants and tasks } \\
\text { with the lowest degree of } \\
\text { implementation }\end{array}$ \\
\end{tabular} & Rating & Level \\
\hline \multirow{2}{*}{$\begin{array}{c}\text { 1. Sufficient } \\
\text { investment support } \\
\text { for the rational use of } \\
\text { nature in the national } \\
\text { economy }\end{array}$} & \multirow[b]{2}{*}{0,346} & \multirow[b]{2}{*}{ Low } & $\begin{array}{c}\text { 1.1. Share of environmental investments } \\
\text { in GDP and budget expenditures }\end{array}$ & 0,23 & Low \\
\hline & & & \begin{tabular}{|c|}
$\begin{array}{l}\text { 1.2. Growth of capital investments, in } \\
\text { particular, in integrated technologies and } \\
\text { research }\end{array}$ \\
\end{tabular} & 0,20 & Very low \\
\hline \multirow{2}{*}{$\begin{array}{l}\text { 2. Investment support } \\
\text { of scientific research } \\
\text { and innovations in the } \\
\text { direction of } \\
\text { sustainable } \\
\text { development } \\
\end{array}$} & \multirow[b]{2}{*}{0,296} & \multirow[b]{2}{*}{ Low } & $\begin{array}{l}\text { 2.1. SDG 9, task 9.5 "Create an } \\
\text { innovation infrastructure" }\end{array}$ & 0,20 & Very low \\
\hline & & & $\begin{array}{l}\text { 2.2. Growth of budget funding for } \\
\text { research and innovation in the priority } \\
\text { area "Environmental Management" }\end{array}$ & 0,19 & Very low \\
\hline \multirow{2}{*}{$\begin{array}{l}\text { 3. Restoration, } \\
\text { sustainable use and } \\
\text { protection of } \\
\text { components of the } \\
\text { natural resource } \\
\text { potential of the } \\
\text { national economy }\end{array}$} & \multirow[b]{2}{*}{0,487} & \multirow[b]{2}{*}{ Average } & $\begin{array}{l}\text { 3.1. SDG 7. Sustainable use of energy } \\
\text { resources }\end{array}$ & 0,30 & Low \\
\hline & & & $\begin{array}{l}\text { 3.2. SDG 6, Task } 6.3 \text { "Reduce } \\
\text { discharges of untreated wastewater" }\end{array}$ & 0,21 & Low \\
\hline \multirow{2}{*}{$\begin{array}{l}\text { 4. Reducing the eco- } \\
\text { destructive impact of } \\
\text { the socio-economic } \\
\text { system on the state of } \\
\text { environment }\end{array}$} & \multirow[t]{2}{*}{0,546} & \multirow[t]{2}{*}{ Average } & $\begin{array}{c}\text { SDG 12, Task } 12.4 \text { "Reduce the amount } \\
\text { of waste generated and increase the } \\
\text { volume of their processing and reuse on } \\
\text { the basis of innovative technologies and } \\
\text { industries" }\end{array}$ & 0,31 & Low \\
\hline & & & Інвестиційний вимір відходоємності & 0,20 & Very low \\
\hline \multirow{2}{*}{$\begin{array}{c}\text { 5. Improving } \\
\text { environmental aspects } \\
\text { of quality of life }\end{array}$} & \multirow{2}{*}{0,613} & \multirow{2}{*}{ Average } & $\begin{array}{l}\text { SDG } 8 \text {, Task } 8.5 \text {. "Promote reliable and } \\
\text { safe working conditions for all workers" }\end{array}$ & 0,20 & Very low \\
\hline & & & Improve the health of the population & 0,35 & Low \\
\hline
\end{tabular}

Source: Compiled by the authors.

The lowest levels of integral evaluation of the degree of implementation were obtained by the first two dominants focused on investment and innovation support for the rational use of natural resources in the national economy (table 4).

Currently, in Ukraine, the main subject of investment and innovation policy of natural resource management is business entities, primarily the industrial sector, which finance $86.9 \%$ (9.9\% more than in 2017) of total expenditures on the environmental protection; the share of other stakeholders decreased from $14.8 \%$ to $6.4 \%$. In the course of the study, versatile structural and dynamic changes in environmental investments in the species and sectoral dimensions were identified. In 2018, compared to 2010, the total cost of environmental protection increased by 2.6 times, while the share of capital investments increased from $21 \%$ to $29.3 \%$, respectively [9]. Based on a quantitative and qualitative evaluation, experts evaluated the degree of implementation of Dominant 1 as "low", which indicates the investment insecurity of rational natural resource management in Ukraine.

A comprehensive evaluation of the tasks of Dominant 2 identified the multidirectional trends in sustainable development in the innovation direction. 
On the one hand, there is a positive trend of growth in the number of low-waste technologies implemented in industry (from $23.5 \%$ in 2010 to $49.3 \%$ ) and an increase in the volume of innovative products sold (by 8\% compared to 2015), on the other hand, its share in the volume of industrial products was only $0.8 \%$, which is significantly lower than the target indicator for $2020(5 \%)$. In 2019, the volume of public expenditures on research and innovation in the direction of sustainable development amounted to 1.4 billion UAH ( $28 \%$ of the total amount of public funds allocated for science and innovation). The share of public spending in the priority areas of sustainable development amounts to $6.1 \%$ for rational natural resource management, $5.1 \%$ for new substances and materials, and $3.1 \%$ for energy and energy efficiency. The degree of implementation of Dominant 2 is assessed by experts as "low".

Analyzing the problem areas in the process of implementing the dominants of the investment and innovation policy of natural resource management, it is necessary to emphasize the close relationship between different dominants, their components and sustainable development tasks in the system of target priorities [10]. An example of such interdependence of strategic priorities of environmental management policy is the reduction of public spending on research and innovation in the direction of sustainable development (Dominant 2) and the sustainable use of natural resource potential (Dominant 3), the level of waste intensity of the economy (Dominant 4), the state of health of the population (Dominant 5).

It is possible to study the relationship between investment support for innovations (Dominant 2) and environmental aspects of the quality of life of the population (Dominant 5). Despite the growth of the share of public spending on the priority area "Life sciences, new technologies for the prevention and treatment of the most common diseases" (from $8.8 \%$ in 2015 to $13.9 \%$ in 2019 ), there is a steady trend towards extremely low funding for some thematic areas, namely: "Genetic and regenerative medicine" $(0.1 \%)$, "Immunobiotechnological research on the development of domestic preventive and diagnostic drugs to detect markers of infection with infectious diseases pathogens" $(0.1 \%)$. In 2019, there was no funding for research in the thematic area "Technology to ensure blood donation in Ukraine and improve its quality" [8]. The degree of implementation of the third dominant of the investment and innovation policy of natural resource management "Restoration, sustainable use and protection of components of the natural resource potential of the national economy", which included six components, is estimated as average. At the same time, the lowest degree of implementation was inherent in the dominant component "Sustainable use of energy resources" and task 6.3. "Reducing the volume of untreated wastewater discharge" SDGs 6 (Table 1). The fourth dominant "Reducing the ecodestructive impact of the socio-economic system on the state of environmental protection" has an average degree of implementation, while the least implemented tasks are in the field of waste management, in particular, their reuse and sufficient investment support for measures in this area. The last dominant "Improving environmental aspects of the quality of life of the population" has the highest degree of implementation and approaches the level of "high average". The problematic tasks in the process of its implementation are to create safe working conditions for all employees, in particular in the field of natural resource management, and improve the health status of the population (Table 1). Based on the obtained results of a comprehensive evaluation of the dominants of the investment and innovation policy of natural resource management, the main directions and ways to increase the degree of implementation of the dominant investment and innovation policy of nature management are justified (Fig. 1). 


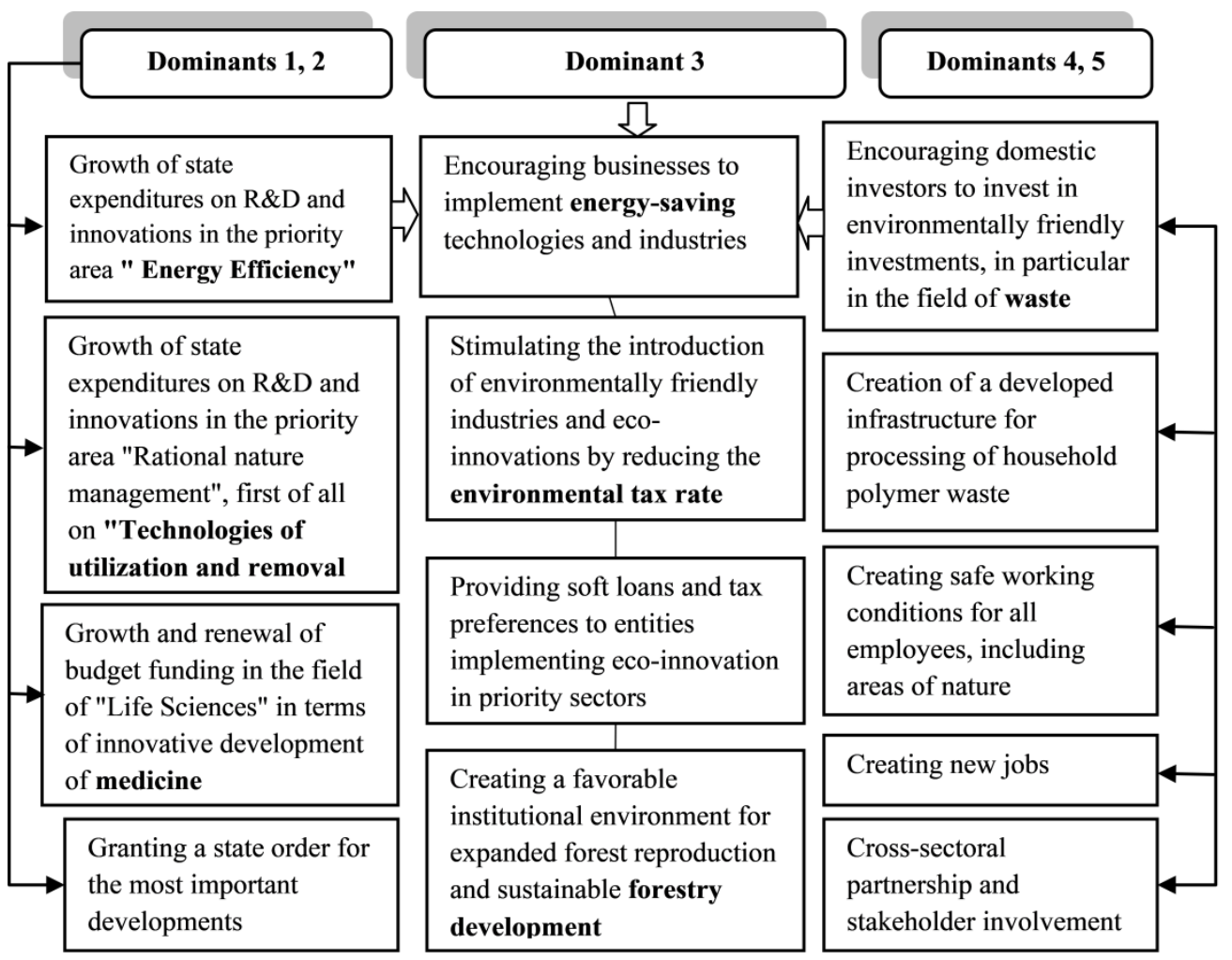

Fig. 1. Directions and ways to increase the degree of implementation of the dominants of investment and innovation policy of nature management in Ukraine [11, 12].

The main direction of increasing the degree of implementation of the first two dominants regarding sufficient investment and innovation support for the rational use of natural resources of the national economy is to increase the volume of state expenditures on research and innovation in the priority areas "Energy efficiency", "Rational use of natural resources", including the thematic area "Technologies for the disposal and removal of PPV", "Life sciences, new technologies for the prevention and treatment of the most common diseases" in terms of innovative development of medicine, as well as the provision of a state order for the most important developments in the direction of sustainable development (Fig.1).

It is also necessary to step up cooperation between representatives of science and state authorities in the course of making managerial decisions and preparing projects of institutes in the direction of sustainable development in Ukraine. That is, the introduction of measures to implement Dominants 1 and 2 through a chain of causal relationships will increase the degree of implementation of other dominants of the investment and innovation policy of natural resource management and their components on an innovative basis.

Practice has shown that the movement towards the SDGs is uneven, Ukraine has reached its target values of 2020 for some sustainable development tasks, and some areas have unrealized potential. For example, the potential of energy efficiency, which "can become a real resource for overcoming crisis phenomena, stabilizing and moving to a resource-saving type of economic growth" [13].

The main directions of increasing the degree of implementation of Dominant 4 are to encourage domestic investors to make environmentally oriented investments, primarily in the field of waste management, creating a developed infrastructure for processing 
household and similar waste (Fig. 1). The National Waste Management Strategy in Ukraine until 2030 No. 820-p of 08.11.2017 provides for an increase in the volume of waste sent for processing from $3.04 \%$ in 2016 to $50 \%$ in 2030 , the creation of new capacities for processing secondary raw materials from 65 to 800 units, for composting biological waste from 20 to 500 units. It also declared a decrease in the total volume of waste to be disposed of from $50 \%$ in 2016 to $35 \%$ in 2030 , and a decrease in the level of household waste disposal from $95 \%$ to $30 \%$ [14].

Among the areas of implementation of Dominant 5, the main place is occupied by the creation of safe working conditions for all employees, including natural resource management, creating new jobs to ensure the inclusive development of the national economy (Fig. 1). Also, a common direction for implementing all target dominants of the investment and innovation policy of natural resource management is to ensure intersectoral partnership and attract stakeholders, in particular, representatives of state and local authorities, science, business, the public and society, to plan and implement the investment and innovation policy of natural resource management based on the principles of sustainable development.

\section{Conclusions}

The analysis of the current methodological approaches to evaluating the effectiveness of the state regional policy and the implementation of the state environmental policy in Ukraine showed that the composition of indicators for a comprehensive evaluation of the investment and innovation policy of sustainable development is insufficient. Based on the methodological scheme for evaluating the effectiveness of environmental policy and grouping of indicators developed by the European Environment Agency, five dominants of the investment and innovation policy of natural resource management were identified, namely: (1) sufficient investment support for the rational use of natural resources of the national economy; (2) investment support for research and innovation in the direction of sustainable development; (3) restoration, sustainable use and protection of components of the natural resource potential of the national economy; (4) reducing the environmentally destructive impact of the socio-economic system on the state of the natural environment; (5) improving environmental aspects of the quality of life of the population. Each dominant needs to introduce appropriate evaluation indicators.

Based on the results of a comprehensive evaluation, the components of the dominant investment and innovation policy of natural resource management and the tasks with the lowest degree of implementation are determined, namely: Dominants 1 and 2, the tasks of improving the energy efficiency of Dominant 3, the tasks of reducing the waste intensity of Dominant 4, the tasks of improving the health status of the population of Dominant 5.

The authors substantiate that the main directions and ways to increase the degree of implementation of the dominant investment and innovation policy of natural resource management, in particular are: (1) growth of public spending on research and innovation in the direction of "Energy and energy efficiency", "Rational use of nature", Renewal of financing of "Life sciences" in the aspect of innovative development of medicine; (2) stimulating business entities to introduce energy-saving technologies, environmentally friendly industries and environmental innovations by reducing the environmental tax rate; (3) Creating a favorable institutional environment for expanded forest reproduction and sustainable development of forestry (4) encouraging domestic investors to make environmentally oriented investments in waste management; (5) developing inter-sectoral partnerships to implement dominant investment and innovation policies for natural resource management. 
The article proves that in conditions of economic uncertainty, the role of the state as an important subject of investment and innovation policy of natural resource management and regulator of natural resource management and environmental protection processes in Ukraine is growing. At the same time, one of the main conditions for implementing the dominants of the investment and innovation policy of natural resource management is the balancing of compulsory-restrictive and incentive-compensatory regulatory methods based on European practices, which will ensure the effectiveness of the investment and innovation policy of sustainable development in Ukraine.

The research was performed within the Research work "Dominants of investment and innovation policy of nature management of the national economy "budget program" Support for the development of priority areas of research" (Code of the budget program 6541230).

\section{References}

1. Verkhovna Rada of Ukraine. (2019). On the Goals of Sustainable Development of Ukraine for the period up to 2030. [Decree of the President of Ukraine of September 30]. https://zakon.rada.gov.ua/laws/show/722/2019

2. Verkhovna Rada of Ukraine. (2015). Strategy of sustainable development of Ukraine until 2030. https://www.undp.org

3. Cabinet of Ministers of Ukraine. (2015). The procedure for monitoring and evaluating the effectiveness of the implementation of state regional policy. [The Resolution of the Cabinet of Ministers of Ukraine No. 856 of 21.11.2015]. https://zakon.rada.gov.ua/laws/show/856 -2015-\% D0\% BF \# Text

4. Friedmann, J., \& Alonso, W. (1975). Regional Policy: Readings in Theory and Applications. Cambridge The MIT Press.

5. Jorgenson, Andrew, K. (2020). Foreign Direct Investment and the Environment, the Mitigating Influence of Institutional and Civil Society Factors and Relationships Between Industrial Pollution and Human Health: A Panel Study of Less-Developed Countries. Organization \& Environment, 22 (2), 135-157.

6. Ortina, H.V., Oleksenko, R.I., \& Yefimenko, L.M. (2019). Innovation as a locomotive of sustainable development of regions. Establishment of a mechanism for public management of territorial development as a priority of the state decentralization policy. $\begin{array}{llll}\text { Collection of scientific works, 225-228. } & \text {. }\end{array}$ http://eprints.mdpu.org.ua/id/eprint/8074/1/zbirnik28112019-225-228.pdf

7. Verkhovna Rada of Ukraine. (2019). On the Basic Principles (Strategy) of the State Environmental Policy of Ukraine for the period up to 2030. [The Law of Ukraine № 2697-VII 28.02.2019]. https://zakon.rada.gov.ua/laws/show/2697-19\#Text

8. Hanneman, S. K. (2008). Design, analysis, and interpretation of method-comparison studies. AACN advanced critical care, 19(2), 223-234. https://doi.org/10.1097/01.AACN.0000318125.41512.a3

9. Jorgenson, Andrew K. (2020). Foreign Direct Investment and the Environment, the Mitigating Influence of Institutional and Civil Society Factors, and Relationships Between Industrial Pollution and Human Health: A Panel Study of Less-Developed Countries. Organization \& Environment. 22 (2), 135-157.

10. Kalamova, M. (2011). Environmental Policy Stringency and Foreign Direct Investment. OECD Environment Working Papers 33, OECD Publishing.

11. UkrINTEI (2016). Implementation of priority areas of science and technology and the results obtained in 2015 [Analytical reference]. 51. https://mon.gov.ua/en/nauka/nauka/informacijno-analitichni-materiali 
12. Yakovlev, A.I. (2018). Analysis of the state of innovation activity in Ukraine and ways to improve it. Nauka ta naukoznavstvo, 2 (100). 29-44.

13. Lir, V.E. (2018). Imperatives and determinants of sustainable energy policy: monograph. Kyiv, DU In-t ekon. ta prohnozuv. NAN Ukrainy.

14. Cabinet of Ministers of Ukraine National. (2017). Waste Management Strategy in Ukraine until 2030 [Order of the Cabinet of Ministers of Ukraine, November 8]. https://zakon.rada.gov.ua/laws/show/820-2017-\%D1\%80\#Text 